\title{
THE ABSOLUTE CHRONOLOGY OF THE ZOOGENIC DEPOSITS FROM THE NEGEV DESERT (ISRAEL)
}

\author{
ANNA N. BABENKO and BULAT F. KHASSANOV \\ A.N. Severtsov Institute of Ecology and Evolution of Russian Academy of Sciences, \\ Leninsky Prt., 33119071 Moscow, Russia
}

Received 2 July 2007

Accepted 26 September 2007

\begin{abstract}
Zoogenic deposits are one of the most important sources of the information on the history of arid ecosystems. Different organic materials form the deposit thus offering an opportunity for palaeobotanic analysis as well as for radiocarbon dating. However, many obstacles arise while dating zoogenic deposits. Some layers can be readily dated by radiocarbon as dung layers, but some of them do not contain any organic material preserved.

Three zoogenic deposits from the central part of the Negev Desert (Israel) were investigated. Azmaut deposit was accumulated more then 5000 years. This deposit is a key object of this research. The Ramon I deposit was accumulated for the last 8000 years.

The observed coincidence of the changes of the deposits and the pollen spectra testifies the presence of common causes driving them. It allows us to compare the spectrum of sufficiently dated Azmaut deposit with that of the poorly dated Bsor one. The bottom layers of the Ramon I deposit were formed 2000 years earlier than that of Azmaut. Combining the results of the pollen analysis and the radiocarbon dating of the three deposits enables us to reconstruct the vegetation history of the region during the last 8000 years.
\end{abstract}

Keywords: holocene, pollen analysis, zoogenic deposit, Israel, radiocarbon dating.

\section{INTRODUCTION}

The Middle East is one of the most ancient centres of animal domestication. Yet the impact of pastoralism on its ecosystems as well as Holocene vegetation history is still poorly understood. Conventional data sources of palaeoecology as peat and lake deposits can be rarely found in arid environments. This is the main cause of the lack of the ecosystem's history information. One of the most promising lines of investigation addressing these questions is research of zoogenic deposits accumulated in caves and niches. Different species of animals have used such shelters for thousands of years. Dung, bones, feathers and other organic materials form the deposit layer by layer from the bedrock of the shelters (Knyazev, 1979).

In the central part of the Negev Desert (Israel), we uncovered seven zoogenic deposits consisting of alternating dung, ash and mineral layers. Identification of preserved faeces showed that ibexes (Capra ibex) as well as

Corresponding author: A.N. Babenko

e-mail: mnemosina_a@mail.ru sheep and goats used these rock shelters (Rosen et al., 2005). Unfortunately it is impossible to tell faeces of wild animals apart from those of ancient domestic ones. The presence of the latter is indicated by a high rate of deposit accumulation. Ibexes do not gather into big flocks and use rock shelters for short periods of time only, so they cannot form thick layers of dung deposit (Dinesman et al., 1989). Ash layers indicate not only the presence of hearths. Humans often burned accumulated dung in order to clean the cave floor. Shepherds of North Caucasus and other regions frequently utilize this method even today (Gamkrelidze, 1986). Evidence obtained in southwest Jordan shows that Middle Eastern shepherds also used to burn dung deposits in rock shelters (Simms and Russell, 1997).

Organic material accumulated at the cave bottom offers an opportunity for analysis of different kinds of plant and animal remains like pollen (Navarro Camacho et al., 2000; Navarro et al., 2001; Scott et al., 2005), macrofossils (Hansen, 2001; Holmgren et al. 2001), phytoliths (Wallis, 2001; Scott, 2002), bones (Andrews, 1990; Tomek and Bocheński, 2005), charcoal (Cowling et al., 
1999; Asouti, 2003) and many others. Reconstructions of ecosystem history based on these analyses must rest on a firmly established absolute chronology. But many obstacles arise while dating zoogenic deposits. Abrupt changes of the deposition rate, including complete interruptions, are frequently found in cave deposits due to different ways of rock shelter utilizations. Events of burning form ash layers. As a result, rather complicated stratigraphy represented by alternating dung, ash and mineral layers can be encountered in cave deposits. Some of these layers, e.g. dung layers, can be readily dated by radiocarbon, but others do not contain any preserved organic material.

The current research is dedicated to the construction of absolute chronology of three zoogenic deposits by combining radiocarbon dating with pollen analysis. The investigated deposits were exposed in the central part of the Negev desert (Fig. 1). Hot summers (average daily air temperature in July is $26.48^{\circ} \mathrm{C}$ ) and relatively cold winters (average daily temperature in January is $10.18^{\circ} \mathrm{C}$ ) characterize this region. Relative humidity is about 40-60\% (Babaev et al., 1986). Atmospheric precipitation usually occurs between October and May; the average annual rainfall does not exceed $100 \mathrm{~mm}$ (Hillel, 1982; Shenbrot, 2004). The central part of the Negev desert is covered with sparse vegetation. Artemisia herba-alba (Compositae), Zigophyllum dumosum (Zigophyllaceae) and Reaumuria negevensis (Tamaricaceae) are abundant on the slopes; while Anabasis siriaca and Hammada scoparia (Chenopodiaceae) dominate over the valley bottoms (Danin, 1983).

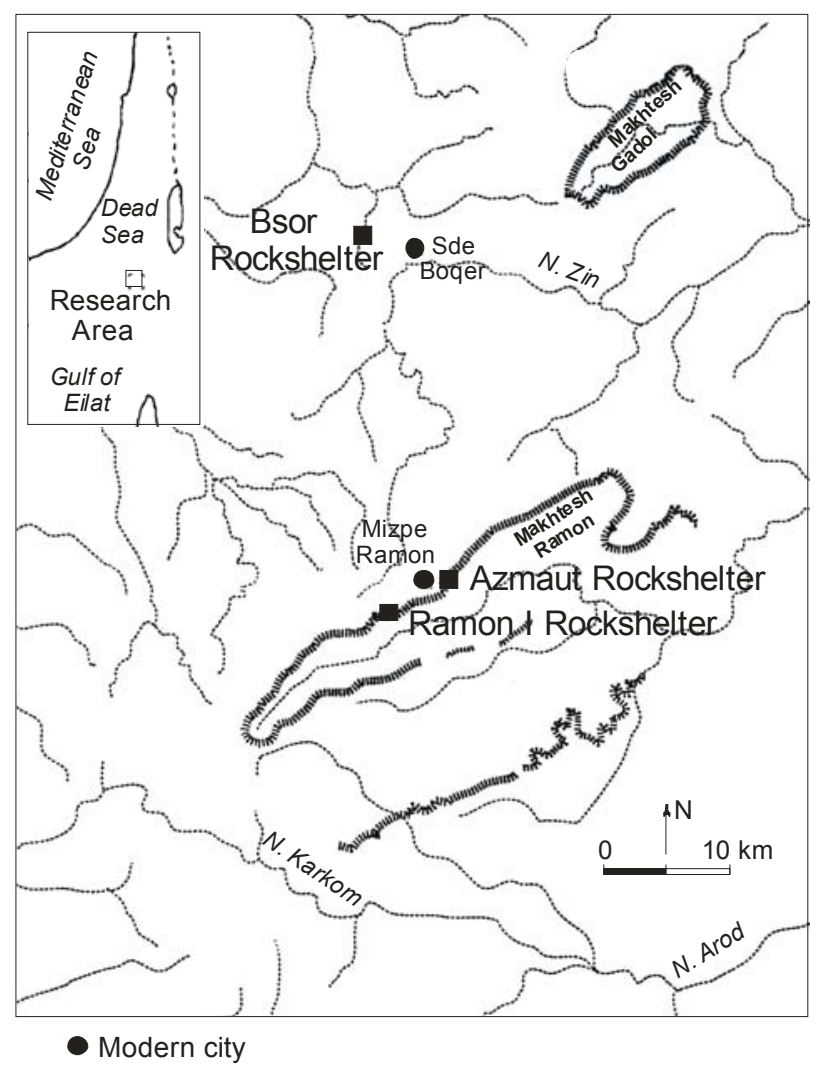

Fig. 1. The central part of the Negev desert, and location of rock shelters.

\section{DESCRIPTION OF THE ZOOGENIC DEPOSIT PROFILES}

The Azmaut rock shelter is located in the upper cliff face of the north wall of the Ramon Crater at the head of the Azmaut Ascent, on the edge of the town of Mitzpe Ramon (N 30³6,458'; E 3448,438'). It faces south and geologically occupies the seam between two limestone formations. The shelter was partially destroyed in the 1950 s with the construction of the paved road leading through the crater. This destruction left an open section, visible from the road now. Azmaut deposit is well stratified due to an alternation of the ash, dung and gravel layers. Its depth is $108 \mathrm{~cm}$ (Fig. 2).

The Azmaut zoogenic deposit consists of:

- 17-20 cm - pressed dung with abundant plant remains,

- 20-29 cm - friable ash layers with charcoal and gravel,

- 29-31 cm - layers of burnt dung with charcoal and gravel,

- 31-51 cm - consolidated sediment of gravel with inclusions of dung,

- 51-64 cm - consolidated sediment of gravel and finegrained material without apparent inclusions of dung,

- 64-79 cm - pressed dung with abundant plant remains,

- 79-95 cm - layers of burnt dung with charcoal and gravel,

- 95-101 cm - pressed dung with abundant plant remains,

- 101-102 cm - friable ash layers with charcoal and gravel,

- $102-111 \mathrm{~cm}$ - pressed dung with abundant plant remains,

- $111-113 \mathrm{~cm}$ - layers of burnt dung with charcoal and gravel,

- $113-116 \mathrm{~cm}$ - pressed dung with abundant plant remains,

- $116-120 \mathrm{~cm}$ - friable ash layers with charcoal and gravel,

- $120-123 \mathrm{~cm}$ - layers of burnt dung with charcoal and gravel,

- $\quad 123-125 \mathrm{~cm}$ - friable layer of gravel without apparent inclusions of dung.

Thus, gravel layers represent one third of Azmaut deposit, while ash horizons, meaning all thermally processed ones, occupy $35 \%$ of it. The remaining portion of the deposit consists of layers of pressed dung.

The Ramon I zoogenic deposit is located in the upper cliff face of the north wall of the Ramon crater as the

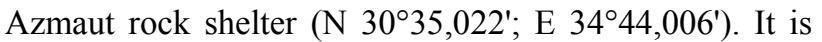
situated about $5 \mathrm{~km}$ from the latter. Ramon I deposit is of $90 \mathrm{~cm}$ in depth; ash layers represent $98 \%$ of it (Fig. 2).

Ramon I zoogenic deposit:

- $7-9 \mathrm{~cm}$ - pressed dung with inclusion of gravel,

- 9-18 cm - layers of burnt dung with charcoal and gravel,

- $18-23 \mathrm{~cm}$ - friable ash layers with charcoal and gravel,

- 23-37 cm - consolidated sediments of ash and gravel, 


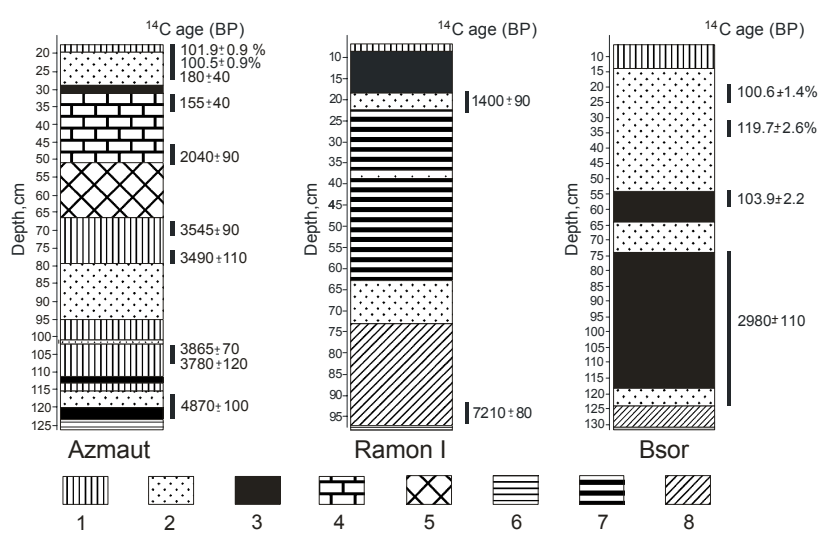

Fig. 2. The profiles of zoogenic deposits. Layers: 1 - pressed dung; 2 - friable ash; 3 - burned dung with inclusions of charcoal; 4 - consolidated sediment of gravel and dung; 5 - consolidated sediment of gravel and fine-grained sediments; 6 - gravel layer; 7 - consolidated sediment of ash and gravel; 8 - gravel with ash and charcoal.

- 37-39 $\mathrm{cm}$ - friable ash layers with charcoal and gravel,

- 39-63 cm - consolidated sediments of ash and gravel,

- 63-74 cm - friable ash layers with charcoal and gravel,

- 74-97 cm - friable gravel with inclusion of bones, charcoal and plant remains.

The Bsor zoogenic deposit is located about $40 \mathrm{~km}$ to the north from Azmaut (N 3055,608'; E 3441,939').

(Fig. 1). It is $126 \mathrm{~cm}$ deep and the ash layers represent 94\% of it (Fig. 2).

Bsor zoogenic deposit:

- $\quad 6-13 \mathrm{~cm}-$ pressed dung with inclusion of gravel,

- 13-54 cm - friable ash layers with inclusion of faeces, charcoal and gravel,

- 54-64 cm - layers of burnt dung with charcoal and gravel,

- 64-74 $\mathrm{cm}$ - friable ash layers with inclusion of faeces, charcoal and gravel,

- 74-118 cm - layers of burnt dung with charcoal and gravel,

- $118-131 \mathrm{~cm}$ - friable gravel with inclusion of char- coal,

- $131-132 \mathrm{~cm}$ - friable gravel.

\section{METHODS}

Sections were cut through the all three deposits and samples for radiocarbon dating and pollen analysis were collected. Charcoal and plant remains extracted from the layers were used for dating. The radiocarbon was measured in the Group of Historical Ecology (A.N. Severtsov Institute of Ecology and Evolution, RAS, former Institute of Evolutionary Morphology and Animal Ecology). Radiocarbon dates were calibrated with OxCal 3.10 computer program (Bronk Ramsey, 1995) with using IntCal 04 calibration curve (Reimer et al., 2004a). CaliBomb computer program was used to calibrate modern ${ }^{14} \mathrm{C}$ data (Reimer et al., 2004b) with the curve for $\mathrm{NH}$ zone 2 (Hua and Barbetti, 2004) and smoothing in years 1.0. The pollen analysis was conducted following Faegri and Iversen (1989). Pollen concentration values were obtained by adding Lycopodium clavatum tablets (batch № 938934) to a specific volume of sediment (Benninghoff, 1962). Pollen diagrams were drawn and a subdivision of pollen sequences into zones was conducted with computer programs TILIA 2.0 (Grimm, 1991-1993) and TILIAGRAPH 1.25 (Grimm, 1991). Stratigraphically, the constrained sum-of-squares (CONISS) cluster analysis (Grimm, 1987) was used.

\section{RESULTS AND DISCUSSION}

The Azmaut deposit was accumulated over more then 5000 years, which was inferred from 10 radiocarbon dates conducted (Table 1). The Azmaut deposit is a key object of this research; it is also being the best dated one. 25 samples were collected for pollen analysis. Total pollen concentration (further TPC) noticeably varies through the Azmaut deposit: from 7000 to 4300000 grains $/ \mathrm{cm}^{3}$. The following palynomorphs are dominant in spectra: Chenopodiaceae, Cruciferae, Gramineae, Liliaceae s.1., and Compositae, including Artemisia.

Two pollen zones (A and $\mathrm{B}$ ) and five subzones were

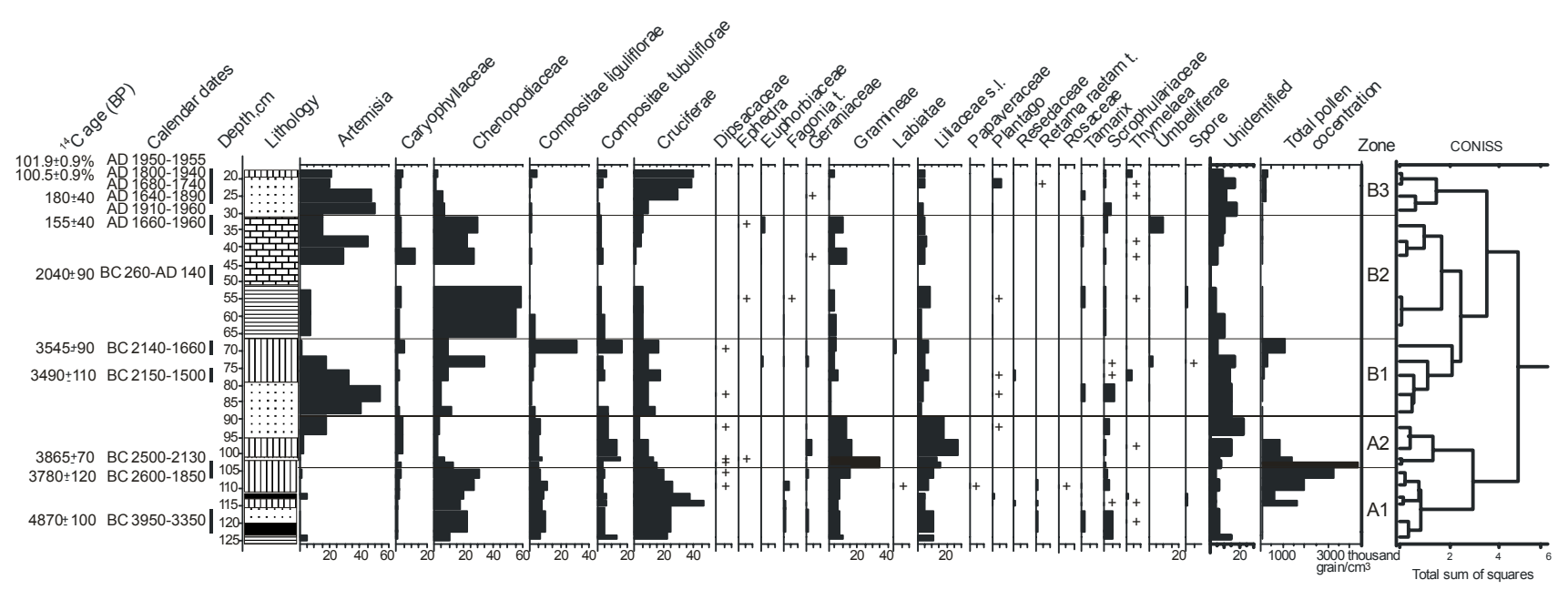

Fig. 3. The profile and the pollen diagram of the Azmaut zoogenic deposit. See legend of Fig. 2. 
Table 1. Radiocarbon and calibrated dates of Azmaut, Ramon I and Bsor zoogenic deposits. Ranges of calendar ages - ranges with confidence level 95\% (IntCal04 Programme, Reimer et al. 2004a).

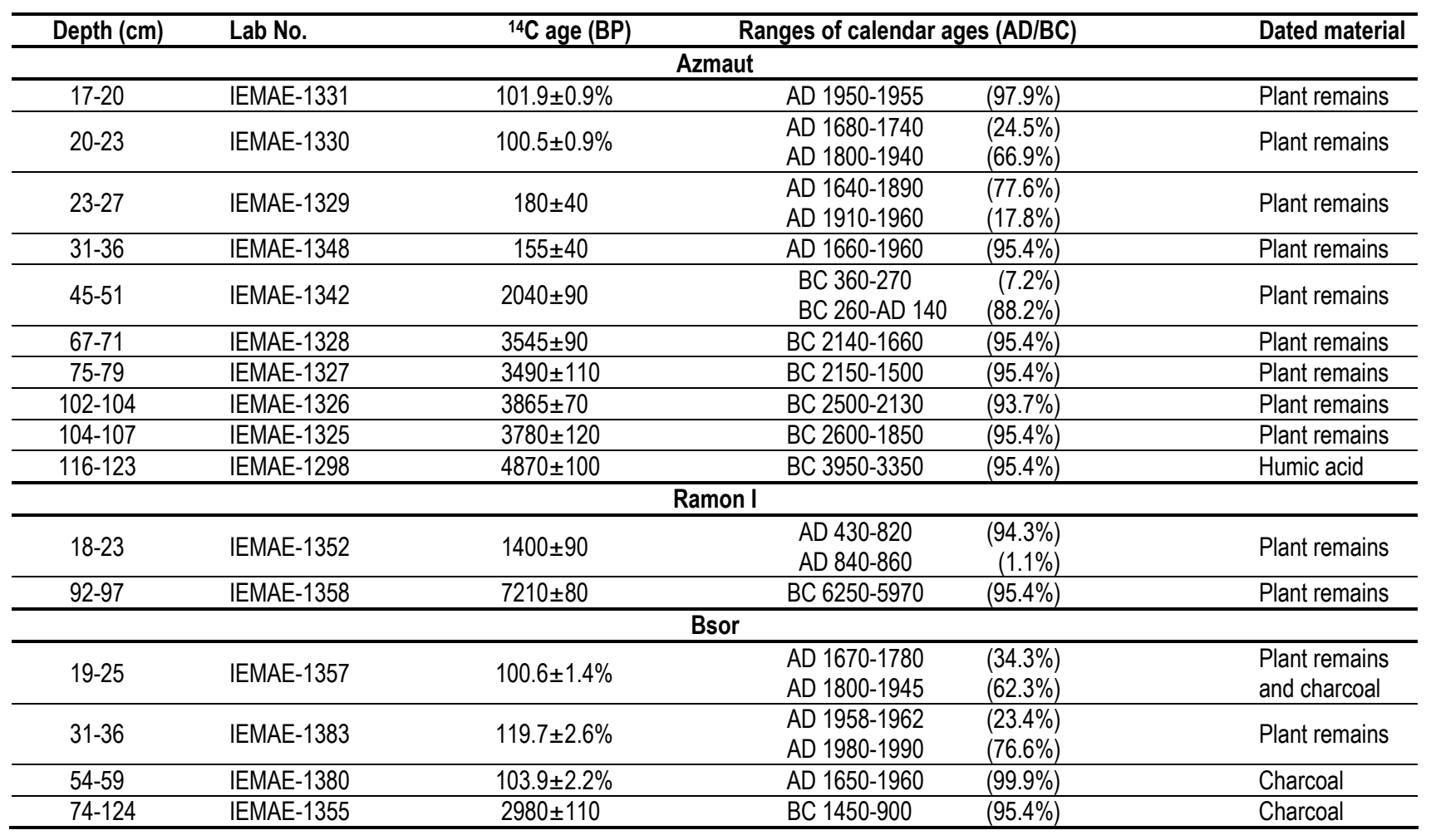

distinguished on the base of cluster analysis (Fig. 3). Zone $\mathrm{A}$ is distinguished from zone $\mathrm{B}$ by both a higher $\mathrm{TPC}$, and a greater proportion of Gramineae and Liliaceae, and consists of two subzones. Zone B is characterized by high share of Artemisia and Chenopodiaceae and consists of three subzones.

Subzone A1 was formed until about $23^{\text {rd }}$ century BC. Crucifers dominate the spectrum, proportions of grasses and liliaceous pile up to $10 \%$. We found the same spectrum in the bottom layers of Ramon I zoogenic deposit.

Only two radiocarbon dates were obtained for Ramon I deposit: one from the upper part and the other from the bottom layer (Table 1). It was accumulating for about eight thousand years. 18 samples were collected for pollen analysis, but pollen concentration in 10 ash layers was too small to conduct reliable counting. There is not a lot of pollen in ash layers because of burning (Brooks and Shaw, 1972).

The bottom layers of Ramon I deposit let us extend pollen spectra of Azmaut deposit back in time. The results of pollen analysis of these two deposits allow us to suggest that from $5^{\text {th }}$ till $3^{\text {rd }}$ millennium $\mathrm{BC}$, the vegetation of the Negev desert differed from that of today in being much more diverse. This difference probably reflects climatic change. Climatic reconstructions show that these three thousand years were unstable but comparatively wetter than nowadays (Bar-Matthews et al., 1998, Migowski et al., 2006).

Considerable increase of proportion of grass pollen along with a peak of total pollen concentration can be seen in the layers of the Azmaut deposit which were dated back to about the $23^{\text {rd }}$ century BC (Fig. 3). These features in pollen spectrum coincide with period of sig- nificantly increased precipitation reconstructed on the base of various climatic proxies. It lasted from the $27^{\text {th }}$ until the $23^{\text {rd }}$ century BC (Bar-Matthews et al., 1998; Migowski et al., 2006). We can suppose that vegetation in the investigated area in this period was close to that of northern Negev today.

The mean amount of annual precipitation in the vicinity of Beer Sheba is about $200 \mathrm{~mm}$, i.e. twice as much as in central Negev (Hillel, 1982). Grasses, mainly annual ones, dominate the vegetation of the northern Negev (Zaady et al., 2001). In spite of the dominance in vegetation, their presence in recent pollen spectra is minor due to low pollen production. It is explained by the fact that most desert species of grasses flower during a short period of precipitation in spring. The maximum of precipitation fell on summer during early and middle Holocene in contrast to recent conditions. Grasses, which are blooming during summer, have much more high pollen productivity (El-Moslimany, 1990). Therefore, the observed changes of vegetation were governed not only by changes of the amount of precipitation alone but also by its seasonal shift.

The same changes in pollen spectra can be seen in Bsor deposit. Three modern radiocarbon dates were obtained for the uppermost part of this deposit (Table 1). 27 samples were collected for pollen analysis. TPC strongly varies through the Bsor deposit: from 6 to 113 grains $/ \mathrm{cm}^{3}$. TPC in one ash layer $(105-111 \mathrm{~cm})$ was too small to conduct reliable counting. Two pollen zones (A and $\mathrm{B}$ ) and five subzones were distinguished on the base of cluster analysis. Zone A is characterized by high proportion of Gramineae and consists of two subzones. 


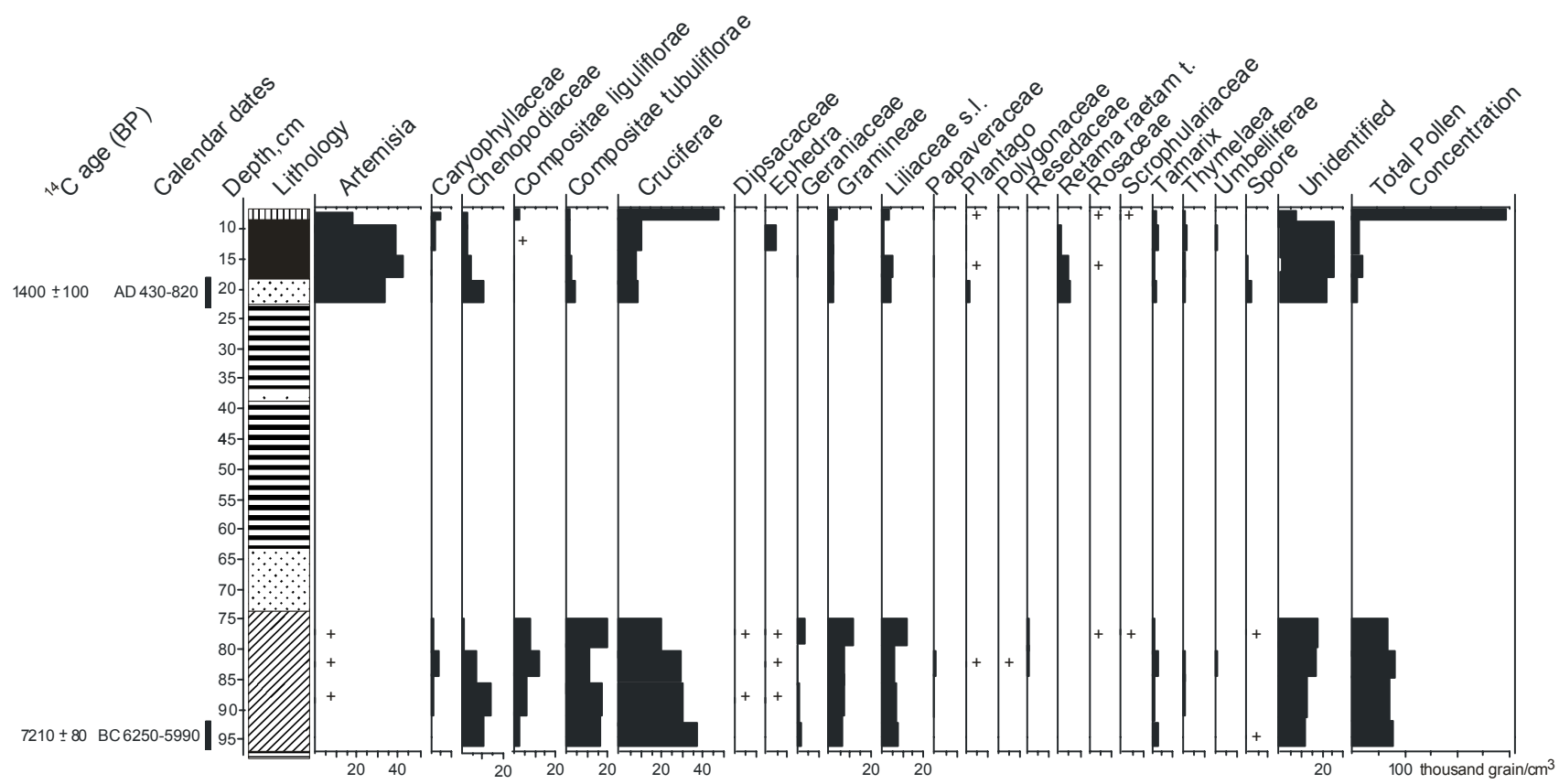

Fig. 4. The profile and the pollen diagram of Ramon I zoogenic deposit. See legend of Fig. 2.

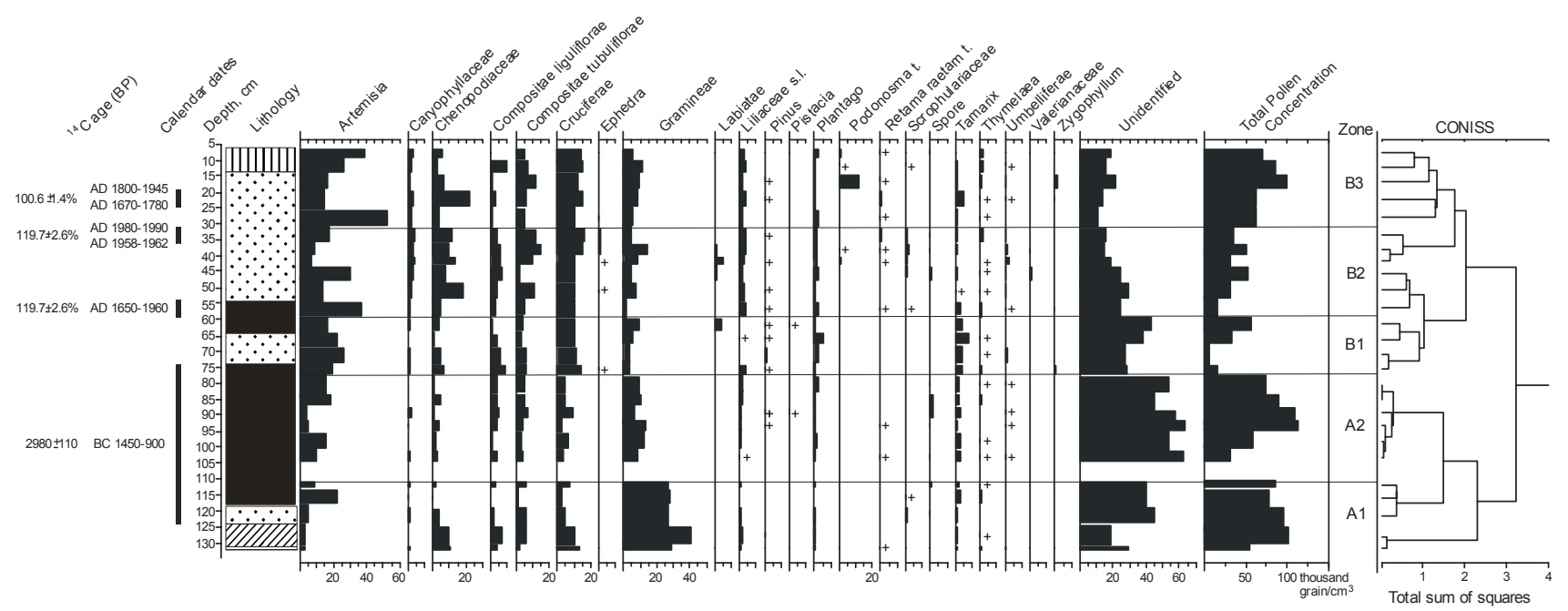

Fig. 5. The profile and the pollen diagram of Bsor zoogenic deposit. See legend of Fig. 2.

Zone B is characterized by high share of Artemisia and Cruciferae and consists of three subzones.

The similarity of pollen spectra of Azmaut and Bsor deposits allows dating the layers of the latter. Lowermost layers of Bsor are characterized by high total pollen concentration and significant proportion of grasses. The same features are distinctive to zone A2 of Azmaut deposit. The latter were formed around $23^{\text {rd }}$ century BC.

In the next four centuries till $19^{\text {th }}$ century BC pollen spectra of the Azmaut deposit were characterized by following features: TPC and the proportion of grasses decreased while the proportion of wormwood reached a high value (Fig. 3). The upper part of subzone A1 and the lower part of subzone A2 of the Bsor deposit display the same changes (Fig. 5). Climatic reconstructions show that at the same time, the amount of precipitation decreased by $20-30 \%$ (Bar-Matthews et al., 1998). This event was not restricted to Middle East only but covered many Mediterranean regions as well as Asian and African ones (Staubwasser and Weiss, 2006).

Significantly increased TPC with an extended proportion of Cruciferae and Compositae and a reduced proportion of Artemisia mark Azmaut deposit layers which were formed about $19^{\text {th }}$ century BC (Fig. 3). The same features characterize subzone A2 of the Bsor deposit (Fig. 5). More wet conditions are reconstructed for the period from the $20^{\text {th }}$ till the $16^{\text {th }}$ centuries BC (Bar-Matthews et al., 1998; Migowski et al., 2006).

Comparison of pollen spectra of the Azmaut and Bsor deposits allows us to propose that the lower half of the latter was formed from $23^{\text {rd }}$ century $\mathrm{BC}$ till the middle of the second millennium BC. This interpretation does not contradict the radiocarbon dates obtained for this horizon (Table 1). Apparently, the accumulation of the Bsor 
deposit was interrupted from the middle of the second millennium BC till recently.

It is also interesting to compare upper layers of the Azmaut, Ramon I and Bsor deposits. They also share common features: significant proportions of wormwood, crucifers and plantain pollen (Figs 3-5).

The increased amount of Artemisia and Plantago pollen can reflect overgrazing (Ward and Olsvig-Whittaker, 1993; Mirkin et al., 2001). It is worth noting that a sharp increase of Artemisia and Plantago pollen concentration is detected in the two uppermost layers of the Azmaut deposit (Fig. 3). The radiocarbon dates obtained for them are modern but they do not show the bomb effect. The still lower dates allow us to suggest that these layers were formed from the end of the 18th till the middle of the $20^{\text {th }}$ century (Table 1). A big group of Bedouins had come in the Negev desert at the end of 18-19 centuries (Bailey, 1985). The same dynamics of wormwood and plantainrose pollen can be seen in the upper layers of the Bsor deposit (Fig. 5).

\section{CONCLUSIONS}

Radiocarbon dating and pollen analysis of these three deposits let us draw the following conclusions:

1) Changes of proportion and concentration of pollen of various plant taxons are synchronous with climatic oscillations and events of anthropogenic impacts.

2) It allows us to compare features of pollen spectra of different zoogenic deposits with each other in order to date layers which cannot be dated by the radiocarbon method.

3) Different zoogenic deposits had different duration of accumulation. Furthermore at least some of them had interruptions in deposition. That is why only investigation of several deposits from given location and an accurate comparison of the results will develop into reliable reconstructions of vegetation.

\section{ACKNOWLEDGEMENTS}

The authors are very grateful to the Ramon Science Centre, Dr. B. Krasnov, Dr. I. Khokhlova and Dr. G. Shenbrot for the help and the organization of field investigations. We are much indebted to Dr. A. Savinetsky and Dr. N. Kiseleva (A.N. Severtsov Institute of Ecology and Evolution of Russian Academy of Sciences), Prof. S.A. Rosen and Dr. J. Plakht (Ben-Gurion University, Israel) for fruitful discussions.

Our study was supported by the Russian Foundation for Basic Research (grant 06-04-48531), Program "The origin and evolution of Biosphere" and Program of basic research DES the Russian Academy of Sciences "Development of technologies of monitoring ecosystem modelling and forecasting in studies of natural resources in arid climate conditions", and also a grant from the Ministry of Science of Israel.

\section{REFERENCES}

Andrews P, 1990. Owls, caves and fossils: Predation, preservation and accumulation of small mammal bones in caves, with an analysis of the Pleistocene cave faunas from Westbury-sub-Mendip, Somerset, $U K$. London. Natural History Museum and University of Chicago Press, Chicago: 231pp.

Asouti E, 2003. Woodland vegetation and fuel exploitation at the prehistoric campsite of Pinarbai, south-central Anatolia, Turkey: the evidence from the wood charcoal macro-remains. Journal of Archaeological Science 30(9): 1185-1201, DOI 10.1016/S03054403(03)00015-3.

Babaev AG, Drozdov NN, Zonn IS and Freikin ZG, 1986. Pustyni (Deserts). Moscow, Misl : 318pp (in Russian).

Bailey C, 1985. Dating the Arrival of the Bedouin Tribes in Sinai and the Negev. Journal of the Economic and Social History of the Orient 28: 20-49.

Bar-Matthews M, Ayalon A and Kaufman A, 1998. Middle to Late Holocene (6500 Yr. period) Paleoclimate in the Eastern Mediterranian region from stable isotopic composition of speleothems from Soreq Cave, Israel. In: Issar AS and Brown N, eds., Water, environment and society in times of climatic change. Netherlands: 203-214.

Benninghoff WS, 1962. Calculation of pollen and density in sediments by addition of exotic pollen in known amounts. Pollen et Spores 6 : 332-333.

Bronk Ramsey C, 1995. Radiocarbon calibration and analysis of stratigraphy: The OxCal Program. Radiocarbon 37: 425-430.

Brooks J and Shaw G, 1972. Geochemistry of sporopollenin. Chemical Geology 10(1): 69-87, DOI 10.1016/0009-2541(72)90078-2.

Cowling RM, Cartwright CR, Parkington JE and Allsopp JC, 1999. Fossil wood charcoal assemblages from Elands Bay Cave, South Africa: implications for Late Quaternary vegetation and climates in the winter-rainfall fynbos biome. Journal of Biogeography 26(2): 367-378, DOI 10.1046/j.1365-2699.1999.00275.x.

Danin A, 1983. Desert vegetation of Israel and Sinai. Jerusalem, Cana Pablishing House: 133pp.

Dinesman LG, Kiseleva NK and Knyazev AV, 1989. Istoriya stepnyh ekosistem Mongol'skoi Narodnoi Respubliki (History of steppe ecosystems of Mongolia). Moscow, Nauka: 215pp (in Russian).

El-Moslimany AP, 1990. Ecological significance of common nonarboreal pollen: examples from drylands of the Middle East . Review of Palaeobotany and Palynology 64(1-4): 343-350, DOI 10.1016/0034-6667(90)90150-H.

Faegri K and Iversen J, 1989. Textbook of pollen analysis. 4th ed. by K. Fægri, P.E. Kaland \& K. Krzywinski. Chichester, John Wiley \& Sons: 328pp.

Gamkrelidze BV, 1986. Iz istorii skotovodstva gornoi Ingushetii (From the stock-breeding history of the Ingushetia mountain). In: Kavkazskiy etnograficheskii sbornik (Caucasian ethnographical articles). Tbilisi, Micniereba 2: 237-247.

Grimm EC, 1987. CONISS: A FORTRAN 77 program for stratigraphically constrained cluster analysis by the method of incremental sum of squares. Computers and Geosciences 13(1): 13-35, DOI 10.1016/0098-3004(87)90022-7.

Grimm E, 1991. TILIA-GRAPH 1.25 (computer software) Illinois State University Research and Collection Center.

Grimm E, 1991-1993. TILIA 2.0 (computer software) Illinois State University Research and Collection Center.

Hansen J, 2001. Macroscopic plant remains from Mediterranean caves and rock shelters: Avenues of interpretation. Geoarchaeology 16(4): 401-432, DOI 10.1002/gea.1010.

Hillel D, 1982. Negev: Land, Water and Life in a Desert Environment. New York, Praeger Scientific: 269pp.

Holmgren CA, Betancourt JL, Rylander KA, Roque J, Tovar O, Zeballos H, Linares E and Quade J, 2001. Holocene Vegetation History from Fossil Rodent Middens near Arequipa, Peru. Quaternary Research 56(2): 242-251, DOI 10.1006/qres.2001.2262.

Hua Q and Barbetti M, 2004. Review of Tropospheric Bomb 14C Data for Carbon Cycle Modeling and Age Calibration Purposes. Radiocarbon 46: 1273-1298.

Knyazev AV, 1979. Investigation of caves zoogenic deposits to ascertain of biogeocenoses history (Issledovanie zoogennyh otlozheniy pescher dlya vyyasneniya istorii biogeocenozov). In: Sokolov VE and Dinesman LG, eds., Obshie metody izucheniya istorii sovremennyh ekosistem (General methods of study of modern ecosystems history). Moscow, Nauka: 129-141 (in Russian).

Migowski C, Stein M, Prasad S, Negendank JFW and Agnon A, 2006. Holocene climate variability and cultural evolution in the Middle East from the Dead Sea sedimentary record. Quaternary Research 66(3): 421-431, DOI 10.1016/j.yqres.2006.06.010. 
Mirkin BM, Naumova LG and Solomeshch AI, 2001. Sovremennaya nauka o rastitel'nosti (Modern vegetation science). Moscow, Logos: 264pp (in Russian).

Navarro Camacho C, Carrion JS, Navarro J, Munuera M and Prieto AR, 2000. An experimental approach to the palynology of cave deposits. Journal of Quaternary Science 15(6): 603-619, DOI 10.1002/1099-1417(200009)15:6<603::AID-JQS544>3.0.CO;2-F.

Navarro C, Carrion JS, Munuera M and Prieto AR, 2001. Cave surface pollen and the palynological potential of karstic cave sediments in palaeoecology. Review of Palaeobotany and Palynology 117(4): 245-265, DOI 10.1016/S0034-6667(01)00095-1.

Reimer PJ, Baillie MGL, Bard E, Bayliss A, Beck JW, Bertrand C, Blackwell PG, Buck CE, Burr G, Cutler KB, Damon PE, Edwards RL, Fairbanks RG, Friedrich M, Guilderson TP, Hughen KA, Kromer B, McCormac FG, Manning S, Bronk Ramsey C, Reimer RW, Remmele S, Southon JR, Stuiver M, Talamo S, Taylor FW, van der Plicht J and Weyhenmeyer CE, 2004a. IntCal04 Terrestrial Radiocarbon Age Calibration, 0-26 cal kyr BP. Radiocarbon 46: 1029-1058.

Reimer PJ, Brown TA and Reimer RW, 2004b. Discussion: Reporting and Calibration of Post-Bomb14C Data. Radiocarbon 46: 12991304.

Rosen SA, Savinetsky AB, Plakht Y, Kisseleva NK, Khassanov BF, Pereladov AM and Haiman M, 2005. Dung in the Desert: Preliminary Results of the Negev Holocene Ecology Project. Current Anthropology 46(2): 317-327.

Scott L, 2002. Grassland development under glacial and interglacial conditions in southern Africa: review of pollen, phytolith and iso- tope evidence. Palaeogeography, Palaeoclimatology, Palaeoecology 177(1-2): 47-57, DOI 10.1016/S0031-0182(01)00351-0.

Scott L, Bousman CB and Nyakale M, 2005. Holocene pollen from swamp, cave and hyrax dung deposits at Blydefontein (Kikvorsberge), Karoo, South Africa. Quaternary International 129(1):4959, DOI 10.1016/j.quaint.2004.04.006.

Shenbrot G, 2004. Habitat selection in a seasonally variable environment: test of the isodar theory with the fat sand rat, Psammomys obesus, in the Negev Desert, Israel. Oikos 106(2): 359-365.

Simms SR and Russell KW, 1997. Tur Imdai Rockshelter: Archaeology of Recent Pastoralists in Jordan. Journal of Field Archaeology 24: 459-472.

Staubwasser M and Weiss H, 2006. Holocene climate and cultural evolution in late prehistoric-early historic West Asia. Quaternary Research 66(3): 372-387, DOI 10.1016/j.yqres.2006.09.001.

Tomek T and Bocheński Z, 2005. Weichselian and Holocene bird remains from Komarowa Cave, Central Poland. Acta Zoologica Cracoviensia 48A(1-2): 43-65.

Wallis LA, 2001. Environmental history of northwest Australia based on phytolith analysis at Carpenter's Gap 1. Quaternary International 83-85: 103-117, DOI 10.1016/S1040-6182(01)00033-7.

Ward D and Olsvig-Whittaker L, 1993. Plant species diversity at the junction of two desert biogeographic zones. Biodiversity Research 1(6): 172-185, DOI 10.2307/2999742.

Zaady E, Yonatan R, Shachak M and Perevolotsky A, 2001. The effects of grazing on abiotic and biotic parameters in a semiarid ecosystem: A case study from the Northern Negev Desert, Israel. Arid Land Research and Management 15(3): 245-261. 